\title{
Expression in Escherichia coli, purification, refolding and antifungal activity of an osmotin from Solanum nigrum Magnólia de A Campos*1,2,3,4, Marilia S Silva ${ }^{3,4}$, Cláudio P Magalhães 1,4, Simone G Ribeiro ${ }^{1,4}$, Rafael PD Sarto ${ }^{1,2,4}$, Eduardo A Vieira ${ }^{3,4}$ and Maria F Grossi de Sá1,4
}

Address: 'EMBRAPA Recursos Genéticos e Biotecnologia, PO Box 02372, 70770-900, Brasília-DF, Brazil, 2Departamento de Biologia Celular, Universidade de Brasília, PO Box 90710-900, Brasília-DF, Brazil, ${ }^{3}$ EMBRAPA Cerrados, BR 020 Km 18, PO Box 08223, 73310-970, Planaltina-DF, Brazil and ${ }^{4}$ Departamento de Biologia, Universidade Federal de Lavras, P.O.Box 3037, 37200-000, Lavras-MG, Brazil

Email: Magnólia de A Campos* - camposma@ufla.br; Marilia S Silva - marilia@cpac.embrapa.br; Cláudio P Magalhães - claudiopicanco@gmail.com; Simone G Ribeiro - simone@cenargen.embrapa.br;

Rafael PD Sarto - rafaelpds83@gmail.com; Eduardo A Vieira - vieiraea@cpac.embrapa.br; Maria F Grossi de Sá - fatimasa@cenargen.embrapa.br * Corresponding author

Published: II March 2008

Microbial Cell Factories 2008, 7:7 doi:10.1 186/1475-2859-7-7
Received: 2I November 2007

Accepted: II March 2008

This article is available from: http://www.microbialcellfactories.com/content/7/I/7

(c) 2008 de A Campos et al; licensee BioMed Central Ltd.

This is an Open Access article distributed under the terms of the Creative Commons Attribution License (http://creativecommons.org/licenses/by/2.0), which permits unrestricted use, distribution, and reproduction in any medium, provided the original work is properly cited.

\begin{abstract}
Background: Heterologous protein expression in microorganisms may contribute to identify and demonstrate antifungal activity of novel proteins. The Solanum nigrum osmotin-like protein (SnOLP) gene encodes a member of pathogenesis-related (PR) proteins, from the PR-5 sub-group, the last comprising several proteins with different functions, including antifungal activity. Based on deduced amino acid sequence of SnOLP, computer modeling produced a tertiary structure which is indicative of antifungal activity.

Results: To validate the potential antifungal activity of SnOLP, a hexahistidine-tagged mature SnOLP form was overexpressed in Escherichia coli MI5 strain carried out by a PQE30 vector construction. The urea solubilized $\mathrm{His}_{6}$-tagged mature SnOLP protein was affinity-purified by immobilized-metal $\left(\mathrm{Ni}^{2+}\right)$ affinity column chromatography. As SnOLP requires the correct formation of eight disulfide bonds, not correctly formed in bacterial cells, we adapted an in vitro method to refold the $E$. coli expressed SnOLP by using reduced:oxidized gluthatione redox buffer. This method generated biologically active conformations of the recombinant mature SnOLP, which exerted antifungal action towards plant pathogenic fungi (Fusarium solani f. sp.glycines, Colletotrichum spp., Macrophomina phaseolina) and oomycete (Phytophthora nicotiana var. parasitica) under in vitro conditions.

Conclusion: Since SnOLP displays activity against economically important plant pathogenic fungi and oomycete, it represents a novel PR-5 protein with promising utility for biotechnological applications.
\end{abstract}

\section{Background}

Plants have evolved a complex array of chemical and enzymatic defenses, both constitutive and inducible, which are not involved in pathogen detection but whose 
effectiveness influences pathogenesis and disease resistance [1]. Plants protect themselves from pathogen invasion through the local expression of a variety of cysteinerich antimicrobial peptides and a set of pathogenesisrelated (PR) proteins [2,3]. Interestingly, most of the components belonging to these two classes of defense proteins are antifungal proteins, even though they are highly divergent in primary structure, in length and exhibit different direct antimicrobial activity.

The family of PR-5 proteins (also known as permatins, thaumatins or osmotins) is part of a larger group of proteins so-called PR-proteins, the last being classified into 17 families (PR-1 to PR-17) [3-5]. Neutral, basic and acid isoforms of PR-5 proteins have been found in plants, all of them consisting of cysteine-rich proteins involved in plant defense responses to several pathogens and abiotic stresses. Many PR-5 genes are activated by different signals such as abscisic acid, ethylene, auxin, salinity, lack of water, cold, UV light, wounding, virus and fungal/oomycete infection, that result in PR-5 protein accumulation in plant cells [6-8].

Different activities have been ascribed to the members of this family [9-13], especially antifungal/antioomycetal in vitro and in planta activity for most of them $[14,15]$. It is not known how PR-5 proteins exert the antifungal activity demonstrated through in vitro inhibition of hyphal growth and spore germination, spore lysis and reduction in viability of germinated spores. It has been proposed that they may act by permeabilization of fungal membranes or interaction with fungal membrane receptors $[13,15-19]$. In addition, it has been demonstrated that a number of PR-5 proteins bind $\beta$-1,3-glucan and have detectable in vitro $\beta$-1,3-glucanase activity [20,21]. Moreover, a tobacco osmotin induces apoptosis in Saccharomyces cerevisiae [22]. Nevertheless, the molecular mechanisms of membrane permeabilization, interaction with fungal receptor or apoptosis remain not completely understood.

Intensive efforts have been undertaken to find PR-5 genes encoding for novel putative antifungal proteins, which could be used in agricultural and/or pharmaceutical biotechnological approaches to control fungal diseases. In this context and based on previously published evidences, wild Solanum plant species represent a valuable source of natural plant resistance against many fungi and oomycetes, in which PR-5 proteins might be involved [23-26]. However, in order to evaluate the potential of these proteins as source of plant resistance, their ability to display antifungal activity needs to be proven experimentally. In order to test and characterize the in vitro activity of a particular protein, the first step is to purify the functional protein in large scale $[27,28]$.
Supporting these claims, the majority of PR-5 proteins have been purified from plant native conditions. The demonstration of the antifungal activity of a PR- 5 protein predicted from gene sequence requires its in vivo (cell system or in planta) expression by and purification from a heterologous systems [13,29-31]. In a previous work, we have described the isolation and cloning of a gene $(S n O L P)$ coding for a neutral osmotin-like protein from Solanum nigrum var. americanum [32]. Based on deduced amino acid sequence of the SnOLP protein, a computer modeling produced a structure that is indicative of antifungal activity. Herein, it is described the validation of SnOLP activity against plant pathogenic fungi and oomycete. This validation was performed by expression of the SnOLP gene in Escherichia coli, followed by purification of mature SnOLP and subsequent in vitro refolding, what generated biologically active conformations of the protein.

\section{Results}

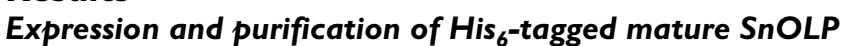
The hexahistidine $\left(\mathrm{His}_{6}\right)$-tagged mature form of a neutral osmotin-like protein from Solanun nigrum L. var. americanum (SnOLP) was overexpressed in E. coli heterologous system by using PQE30 expression vector and purified by using immobilized-metal $\left(\mathrm{Ni}^{2+}\right)$ affinity chromatography (IMAC). Since bacterial expression systems do not perform certain post-translational processing, deletion mutations were generated by PCR amplification from the previously cloned $S n O L P$ gene [32] to produce a mature SnOLP form lacking its signal peptide and its carboxy-terminal peptide. This PCR product was cloned into the pQE30 vector, which contains an inbuilt His $_{6}$-tag sequence, what resulted into a $\mathrm{His}_{6}$-tagged mature SnOLP coding sequence (pQE30-SnOLP construct, Fig. 1). The expected $\mathrm{His}_{6}$-tagged mature SnOLP protein is 225 amino acids in length with a theoretical $M_{r}$ of $24,363 \mathrm{KDa}$, calculated from deduced amino acid sequence (ExPASY Protein Parameters Tools Analysis).

In order to obtain information on the solubility of bacterially produced $\mathrm{His}_{6}$-tagged mature $\mathrm{SnOLP}$, this protein was expressed in IPTG-induced M15 E. coli cells carrying the pQE30-SnOLP construct. Total cell protein fraction was obtained from non-induced and induced bacterial cells lysed under native conditions. Then soluble and insoluble protein fractions from induced protein fractions were separated by centrifugation. Equal amounts of total, soluble and insoluble protein fractions were analyzed on $12 \%$ SDS-PAGE (Fig. 2A). A protein presenting a mass around the predicted $M_{r}$ of the $\mathrm{His}_{6}$-tagged mature SnOLP was present in high amounts within the induced total protein fraction as compared to the non-induced total protein fraction (Fig. 2A, lanes 2 and 3). The majority of the probable $\mathrm{His}_{6}$-tagged mature SnOLP is present within the 


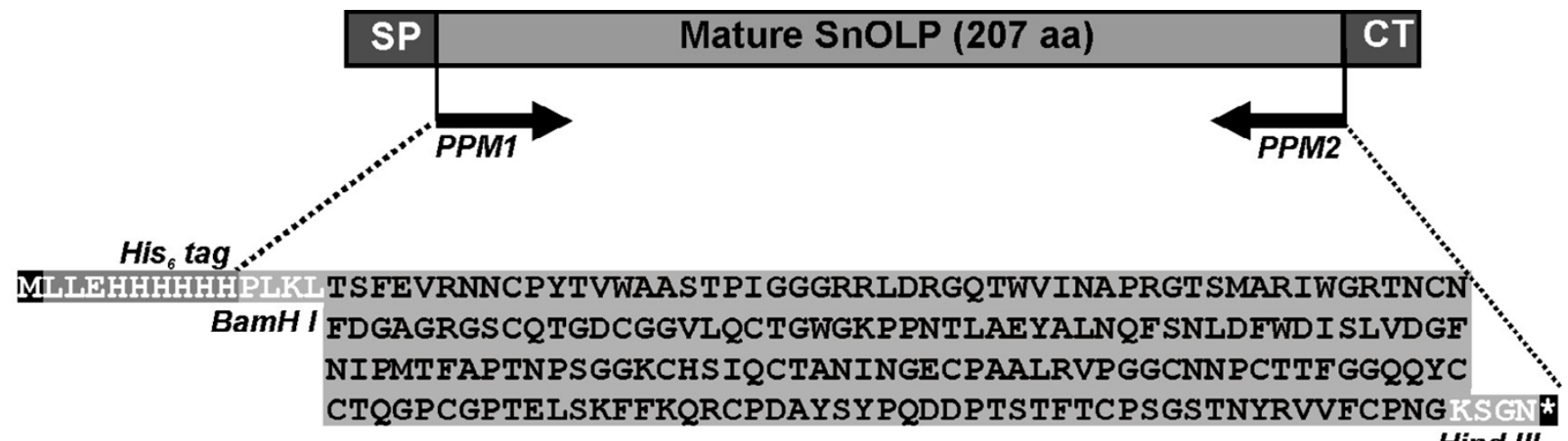

Hind III

Figure I

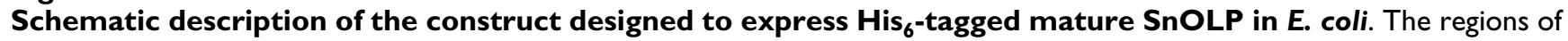
the preproprotein SnOLP are shown. The positions of the primers used to generate fragments coding for mature SnOLP form are shown. The orientations of the primers PPMI and PPM2, including the respective restriction cloning sites, are indicated by arrows. The $\mathrm{His}_{6}$-tag encoded by the PQE30 vector is indicated. SP, Signal Peptide; CT, Carboxy-Terminal propeptide; $\mathbf{M}$, Methionine; *, Stop codon.

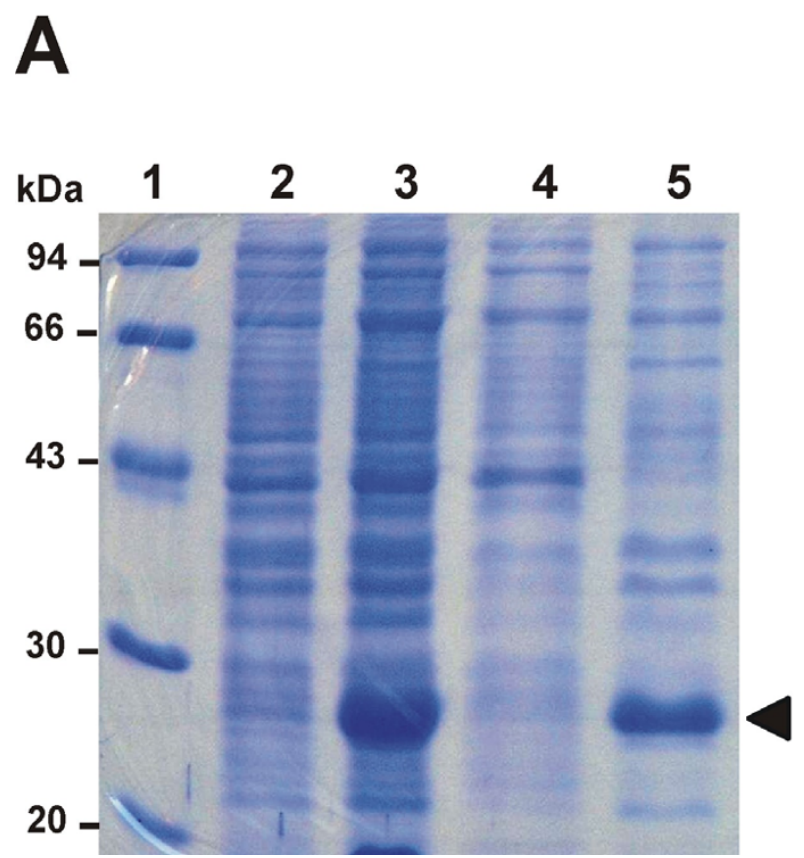

\section{B}
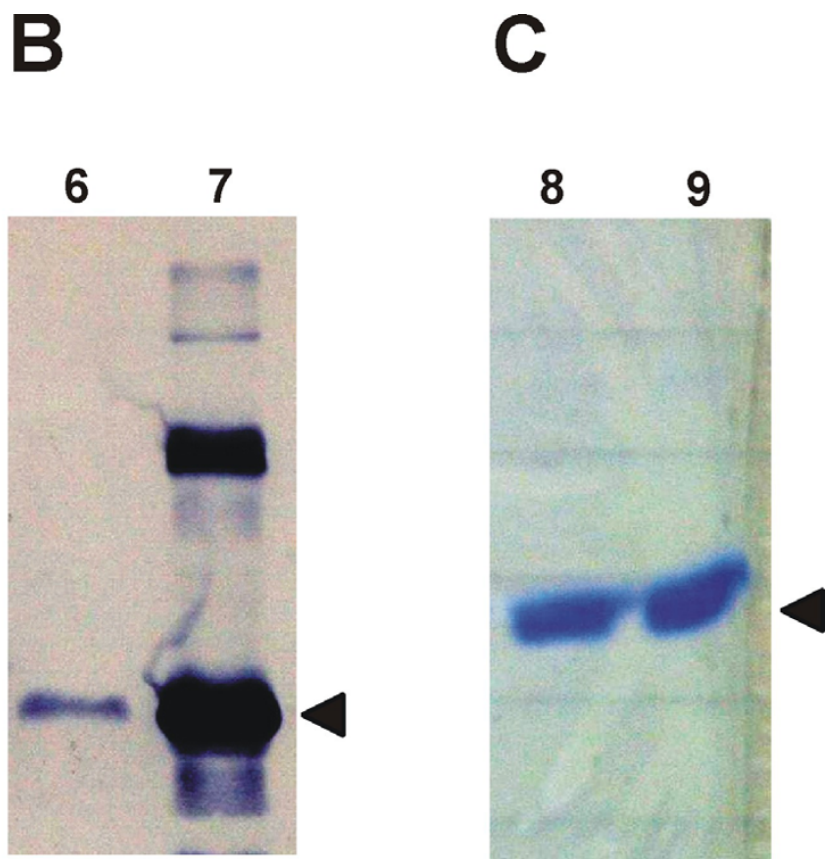

Figure 2

Expression of $\mathrm{His}_{6}$-tagged mature SnOLP in E. coli, solubilization and purification. A. SDS-PAGE analysis of the expression of $\mathrm{His}_{6}$-tagged mature $\mathrm{SnOLP}$ in $\mathrm{E}$. coli cultures incubated at $37^{\circ} \mathrm{C}$ for $3 \mathrm{~h}$ and induced by $0.4 \mathrm{mM}$ IPTG (when indicated). I. Molecular mass marker (LMW, Amersham Pharmacia Biotech); 2. Total protein fraction from non-induced $E$. coli culture; 3. Total protein fraction from IPTG-induced $E$. coli culture; 4. Soluble protein fraction from IPTG-induced E. coli culture; 5. Insoluble protein fraction from IPTG-induced E. coli culture. B. Western blot analysis of expressed $\mathrm{His}_{6}$-tagged mature $\mathrm{SnOLP}$ probed with $\mathrm{His}_{6}$-monoclonal antibody. 6. Soluble protein fraction from IPTG-induced E. coli culture; 7. Insoluble pro-

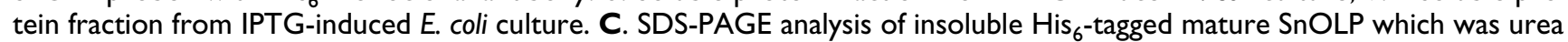
solubilized and subsequently purified by immobilized-metal $\left(\mathrm{Ni}^{2+}\right)$ affinity chromatography (IMAC). 8 and 9 . Eluates from IMAC. In $\mathbf{A}$. and $\mathbf{C}$. the gels were stained with Coomassie brilliant blue. His ${ }_{6}$-tagged mature SnOLP protein is indicated by arrow heads. 
insoluble protein fraction, as compared to the soluble protein fraction (Fig. 2A, lanes 4 and 5), and represents around a third of the total protein fraction contents. As confirmed by Western blotting, low quantity of the $\mathrm{His}_{6}{ }^{-}$ tagged mature SnOLP is present within the soluble fraction whereas high quantity is detected within the insoluble fraction (Fig. 2B, lanes 6 and 7). Curiously, an extra band, higher than the putative $\mathrm{His}_{6}$-tagged mature SnOLP, is present within the insoluble fraction though absent in the soluble fraction (Fig. 2B, lanes 6 and 7). This extra band may be due to dimeric forms of the $\mathrm{His}_{6}$-tagged mature SnOLP.

Supported by these findings, an expression in a larger scale, in order to purify $\mathrm{His}_{6}$-tagged mature SnOLP, was performed by $E$. coli culture incubated at $37^{\circ} \mathrm{C}$ for $2 \mathrm{~h}$ after expression induction by IPTG $0.4 \mathrm{mM}$. This larger scale expression protocol produced high quantities of insoluble $\mathrm{His}_{6}$-tagged mature SnOLP, which was subsequently ureasolubilized and purified by IMAC under denaturing conditions. SDS-PAGE analysis of IMAC eluates revealed that purification of the bacterially expressed and solubilized $\mathrm{His}_{6}$-tagged mature SnOLP provided virtually $100 \%$ pure protein, as evident by the single band detected in two representative IMAC eluates (Fig. 2C, lanes 8 and 9). These procedures led to elevated yields of high quality pure and soluble, though denatured, $\mathrm{His}_{6}$-tagged mature SnOLP $(\sim 1 \mathrm{mg} / \mathrm{mL}$ ) from $500 \mathrm{~mL}$ of induced E. coli culture. In order to promote the recovery of steric structures and biological activity of the pure soluble denatured $\mathrm{His}_{6}$-tagged mature SnOLP, the fusion protein was slowly renatured in buffer containing a redox state maintained by reducedglutathione:oxidized-glutathione pair, followed by dialysis against water. No significant precipitation was observed during or after refolding.

\section{In vitro antifungal activity studies using $\mathrm{His}_{6}$-tagged mature SnOLP}

The activity of the refolded His $_{6}$-tagged mature SnOLP was determined by in vitro inhibition of mycelial growth of one plant oomycete (Phytophthora nicotiana var. parasitica) and four plant fungi (Fusarium solani f. sp. glycines, Macrophomina phaseolina, Colletotrichum gloesporioides, Colletotrichum gossypii var. cephalosporioides). The tested concentrations of refolded $\mathrm{His}_{6}$-tagged mature SnOLP were $0,1 \mu \mathrm{g} / \mu \mathrm{L}, 0,2 \mu \mathrm{g} / \mu \mathrm{L}$ and $0,3 \mu \mathrm{g} / \mu \mathrm{L}$, corresponding to total doses of 1, 2 and $3 \mu \mathrm{g}$ of SnOLP, respectively (Fig. 3). A dose of $10 \mu \mathrm{g}$ BSA (negative control) at the concentration of $1 \mu \mathrm{g} / \mu \mathrm{L}$ had no effect on mycelial growth of any fungi (Fig. 3B and data not shown) or oomycete (Fig. 3A), as expected. On the other hand, a dose of $2000 \mathrm{U}$ of the pharmaceutical fungicide Nistatin (positive control), at the concentration of $200 \mathrm{U} / \mu \mathrm{L}$, inhibited the mycelial growth of all four fungi (Fig. 3B and data not shown) tested but not of the oomycete (Fig. 3A), also as expected.
The highest concentration tested to achieve the maximum inhibitory activity of SnOLP against the four fungi and the oomycete was $0,3 \mu \mathrm{g} / \mu \mathrm{L}$ (Fig. 3). The sensitivity of almost all pathogens to SnOLP increased at growing concentrations of the protein (Fig. 3C, D, E, G), except for Colletotrichum gossypii var. cephalosporioides, which was equally sensitive to SnOLP at both 0,2 and $0,3 \mu \mathrm{g} / \mu \mathrm{L}$ concentrations (Fig. 3F). Macrophomina phaseolina was the only pathogen tested which was not sensitive to SnOLP at the concentration $0,1 \mu \mathrm{g} / \mu \mathrm{L}$ (Fig. 3B, D). In summary, these results prove that SnOLP directly inhibits growth of the pathogens tested, in a dose and concentration dependent manner.

\section{Discussion}

In this work, we report the successful expression, purification, refolding and antimicrobial activity of the neutral $\mathrm{His}_{6}$-tagged mature SnOLP, a Solanum nigrum var. americanum osmotin belonging to the antimicrobial PR-5 protein family. The results demonstrated that SnOLP is effective against several agronomically important plant pathogens. SnOLP, as well as other neutral and basic members of the PR-5 protein family, require the formation of eight disulfide bonds for its biological activity and are synthesized in plants as an inactive precursor (i.e. preproprotein). In general, the preproprotein precursor contains an $\mathrm{N}$-terminal signal peptide, which mediates the transport of the protein through the secretory pathway $[33,34]$, and an additional carboxy-terminal extension, which may be removed during or after transport to the plant vacuole $[29,34,35]$. Although bacterial expression systems neither perform certain post-translational modifications (such as removal of signal peptides) nor form all disulfide bonds of eukaryotic proteins correctly, it is still a faster and cheaper system for heterologous expression than other eukaryotic cell systems, such a yeast, insect or mammalian cells. Therefore, we chose to adapt an E. coli expressing system coupled with in vitro post-expression refolding to successfully produce high amounts of active forms of SnOLP.

In order to express mature SnOLP in E. coli, the signal peptide and the carboxy-terminal extension from the prepro SnOLP ORF [32] was deleted by PCR-engineering, and the resulting PCR-fragment was cloned into the bacterial expression vector $\mathrm{pQE30}$, which encodes a $\mathrm{His}_{6}$-fusion tag. The resulting pQE30-SnOLP construct was introduced into E. coli for the expression of $\mathrm{His}_{6}$-tagged mature SnOLP. The conditions herein established to overexpress His $_{6}$-tagged mature SnOLP in E. coli (induction with 0.4 $\mathrm{mM}$ IPTG and incubation at $37^{\circ} \mathrm{C}$ for $3 \mathrm{~h}$ ) led to formation of protein inclusion bodies, abundantly present within the insoluble protein fraction. This appears to be frequently observed when proteins are overexpressed and exceed around $30 \%$ of the total host cell protein contents. Inclusion bodies, amyloids and protein precipitation are 
A

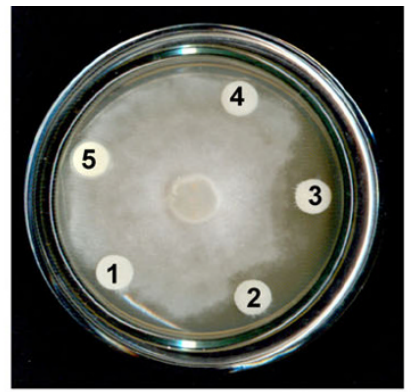

C

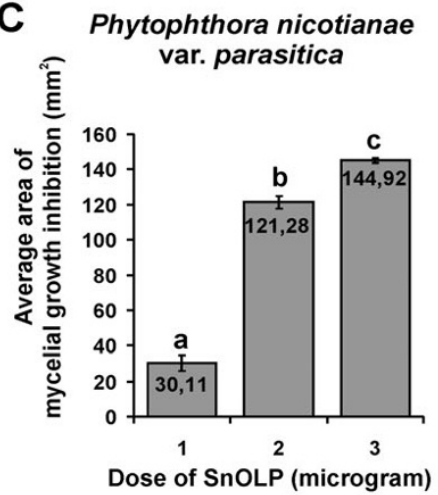

B
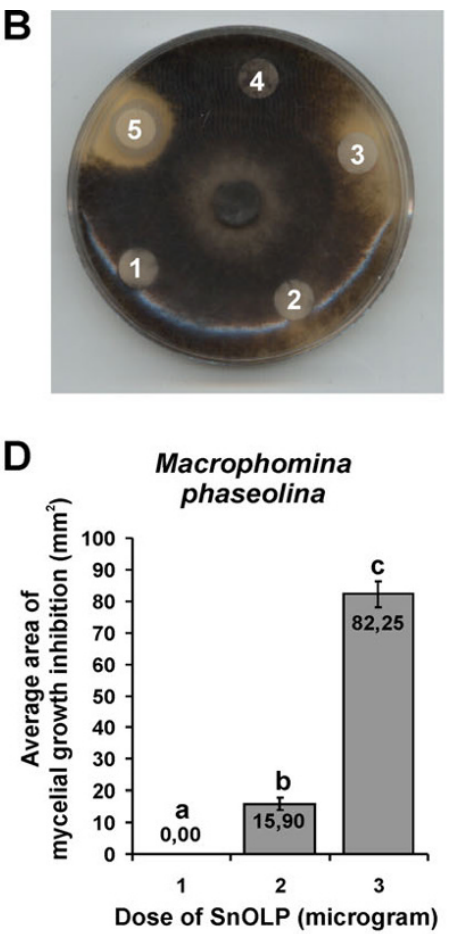
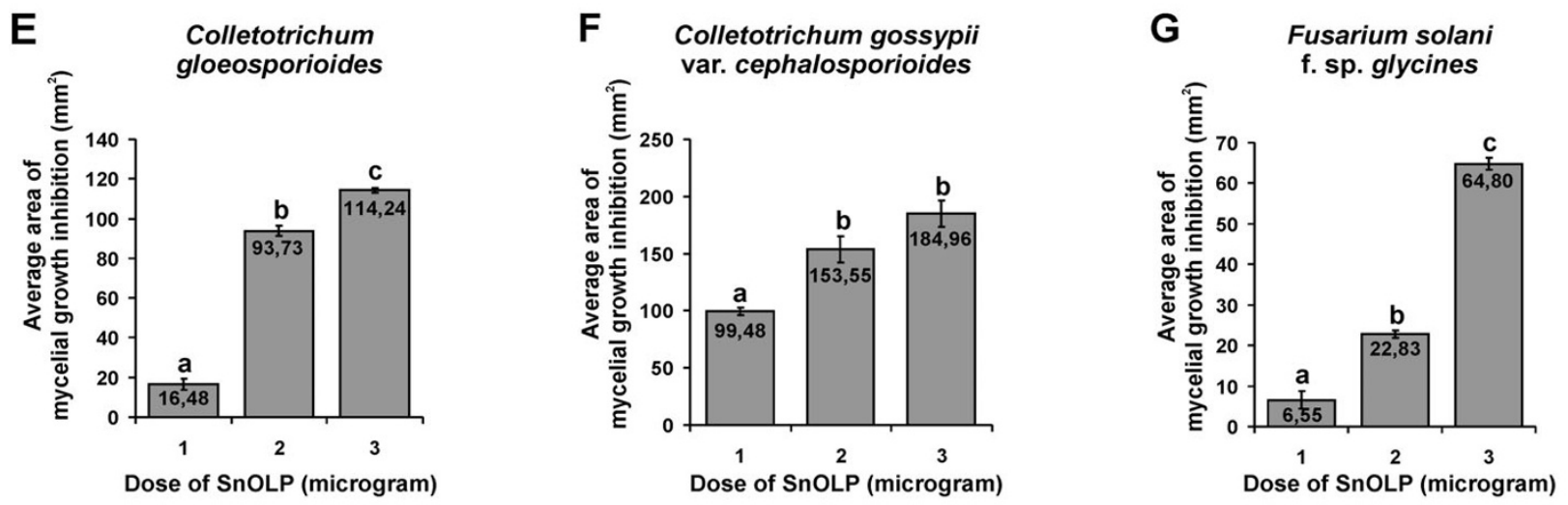

Figure 3

Bioassays of the mycelial growth inhibition activity of purified and renatured $\mathrm{His}_{6}$-tagged mature SnOLP. A-B. Representative bioassay Petri dishes. Filter paper discs containing $10 \mu \mathrm{L}$ of test proteins were placed on plates 3 days after inoculation with fungal mycelia (plugs). Petri dishes were incubated at $29^{\circ} \mathrm{C}$ during the entire bioassay. Inhibitory effects of purified and renatured $\mathrm{His}_{6}$-tagged mature SnOLP upon the fungi are observed as areas lacking mycelial growth. A. Phytophthora nicotiana var. parasitica; I day after adding protein (a.a.p.); B. Macrophomina phaseolina, 5 days a.a.p. I-3. Corresponds to

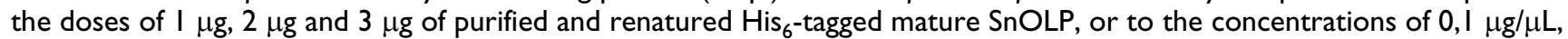
$0,2 \mu \mathrm{g} / \mu \mathrm{L}$ and $0,3 \mu \mathrm{g} / \mu \mathrm{L}$, respectively; 4 . Corresponds to the dose of $10 \mu \mathrm{g}$ of Bovine Serum Albumin (BSA), or to the concentration of I $\mu \mathrm{g} / \mu \mathrm{L} ; \mathbf{5}$. Corresponds to the dose of $2000 \mathrm{U}$ Nistatin, or to the concentration of $200 \mathrm{U} / \mu \mathrm{L}$. C-F. Average area $\left(\mathrm{mm}^{2}\right)$ of mycelial growth inhibition caused by renatured $\mathrm{His}_{6}$-tagged mature SnOLP, as measured (software UTHSCSA Image Tool, Version 3.00 [57]) in three replicates, similar to the bioassay Petri dishes shown in A and B, for each fungus/oomycete and for each dose/concentration of SnOLP separately. Standard deviation bars are shown for each average column. The averages were statistically compared by using ANOVA and Tukey Test at the probability level of I\% (software Genes [58]). Different letters above the average columns (i.e. a, b and c), indicate that the average values were considered to be statistically different among each other, whereas statistically identical average values are indicated by the same letter. $\mathbf{C}$. Phytophthora nicotiana var. parasitica; I day after adding protein (a.a.p.); D. Macrophomina phaseolina, 5 days a.a.p. ; E. Colletotrichum gloeosporioides, 12 days a.a.p.; F. Colletotrichum gossypii var. cephalosporioides, 5 days a.a.p.; G. Fusarium solani f. sp. glycines, 5 days a.a.p. 
common manifestations of protein aggregation, in which misfolded protein molecules may be present [36]. However, the probable misfolding of the insoluble $\mathrm{His}_{6}$-tagged mature SnOLP overexpressed in E. coli was successfully repaired by denaturing and subsequent refolding procedures. These corrective procedures resulted in biologically active conformations of the recovered mature SnOLP that, according to results herein shown, exerted antimicrobial action towards plant pathogenic fungi and oomycete. Despite the amount of correctly refolded mature SnOLP was not quantified, the use of reduced:oxidized gluthatione redox buffer, which can produce a mixture of correctly refolded and misfolded protein, folding intermediates and kinetic traps [37], yielded biologically functional SnOLP.

A small number of PR5-like proteins have also been successfully expressed in E. coli in a biologically active form [31,13]. Hu and Reddy [31] demonstrated that an Arabidopsis thaumatin-like protein (ATLP3) could be expressed in E. coli in form of inclusion bodies, purified and that the refolded mature form displayed activity against some pathogenic fungi. Newton and Duman [13] found that an osmotin-like cryoprotective protein from Solanum dulcamara, when expressed in E. coli and directed to periplasmic localization, resulted in high concentrations of the soluble protein with cryoprotective activity, whereas when it was expressed in the bacterial cytoplasm, high amounts of insoluble and aggregated proteins were produced.

Here, we demonstrated that the SnOLP protein, in a refolded fusion-mature form, displays activity against a spectrum of four fungi and one oomycete, which were chosen due to their economical importance as plant pathogens. Sudden death syndrome of soybean (Glycine max (L.) Merr.), caused by several species of Fusarium belonging to the taxonomic section Martiella, among them $F$. solani f. sp. glycines, is a disease of increasing economic importance in soybean producing countries, such as Brazil [38-40]. Moreover, Macrophomina phaseolina, which causes the charcoal rot disease in soybean root and stem, has been considered one of the most prevalent soybean pathogens in Brazil $[41,42]$. Furthermore, Colletotrichum gossypii var. cephalosporioides is cited as the etiological agent of ramulose, one of the most impacting fungal diseases occurring on cotton (Gossypium hirsutum L. var. latifolium Hutch) in Brazil, which provokes super budding of the plant flushing tissues [43]. Phytophthora nicotiana var. parasitica causes root rot and gummosis in citrus (Citrus spp.) worldwide, especially in rootstock plants, leading to serious damage and losses in citrus seedbeds, nurseries, as well as young and mature groves [44-46]. Finally, Colletotrichum gloesporioides causes anthracnoses, a relevant disease occurring on a wide range of plants, including
Stylosanthes guianensis, an important tropical forage plant $[47,48]$. Therefore, the discovery of a protein, such as SnOLP, that affects the growth of these pathogens could be of uppermost relevance for the transgenic control of these diseases in economically important crops.

As shown in Figure 3, the sensitivity of the pathogens to SnOLP appears to be species specific, since different levels of sensitivity were observed among unrelated pathogen species. Nevertheless, all the tested pathogens were sensitive to 2 and $3 \mu \mathrm{g}$ of refolded $\mathrm{His}_{6}$-tagged mature SnOLP. Abad et al. [15] demonstrated that 30, 60 e $100 \mu \mathrm{g}$ of a native tobacco osmotin had no effect against Macrophomina phaseolina. Likewise, in the presence of $100 \mu \mathrm{g}$ of the referred tobacco protein, the mycelial growth of Colletotrichum gloesporioides was slightly inhibited. The mycelial growth of Fusarium spp. was considered only weakly inhibited, and also the inhibition of Phytophthora spp. was visible as a discrete zone beyond the protein disc [15]. Our results demonstrate that SnOLP exerts in vitro inhibitory effect upon mycelial growth of the tested pathogens, though some of these pathogens are not sensitive to the before mentioned tobacco osmotin [15].

Another osmotin isolated from Solanum nigrum, denoted as SniOLP and which is $99 \%$ identical to SnOLP, when expressed in E. coli and subsequently refolded, exerted antifungal activity against Rhizoctonia batiticola and Sclerotinia sclerotiorum [49]. Therefore, it is very likely that SnOLP also presents activity against these fungi. Some osmotins present endo- $\beta$-1,3-glucanase activity, which is speculated to be involved in the antifungal mechanism of action of osmotins [50,51]. Similarly to SniOLP, which does not present endo- $\beta$-1,3-glucanase activity, SnOLP most like does not have glucanase activity as well.

Our results are relevant from a biological point of view, since the SnOLP gene was isolated from a solanaceous weed, Solanum nigrum var. americanum, common in the Americas. It was reported that a quite similar species, an European $S$. nigrum variety, is a nonhost plant possessing resistance to Phytophthora infestans, a destructive oomycete causing late blight disease in potato [24]. In addition, it was demonstrated that the penetration of $S$. nigrum leaf epidermis by $P$. infestans was accompanied by rapid Hypersensitive Response of plant cells, within $22 \mathrm{~h}$ after inoculation, what resulted in abortion of the infection $[52,53]$. Evidences pointed out that the constitutive expression of PR genes, including PR-5, may contribute to non-specific host resistance to $P$. infestans [26] and that PR-5 proteins are induced in potato in response to infection by this pathogen $[7,54]$. However, no indication for a participation of PR-5 proteins in nonhost resistance response was given so far. Here we provided one more evidence for the specific antioomycetal effect of PR-5 pro- 
teins targeted to Phytophthora spp. Despite of the lack of ultimate evidence, we hypothesize that the SnOLP gene might also be involved in basal defense responses to oomycetes and/or fungi in Solanum nigrum. Further analysis will contribute to elucidate a possible biological function or involvement of the SnOLP gene in defense responses of $S$. nigrum to pathogens.

\section{Conclusion}

We report here the successful overexpression in E. coli, purification, refolding and antifungal activity of the SnOLP osmotin from S. nigrum. The herein demonstrated inhibition of in vitro mycelial growth of economically important pathogens of soybean, cotton and citrus by SnOLP reveals promising features for biotechnological applications, being this is a subject of our current researches.

\section{Methods \\ Construction of expression vector, cloning and transformation of $\mathrm{E}$. coli}

The isolation of SnOLP gene and used primers were described previously by Campos et al. [32]. The complete open reading frame (ORF) sequence coding for the wild type preproprotein SnOLP (GenBank accession no $\underline{\text { AF450276) }}$ was amplified by PCR from black nightshade(Solanum nigrum var. americanum) genomic DNA [32]. This ORF was used as template to prepare the prepro-truncated form (Figure 1). The prepro-truncated form, coding for mature SnOLP protein, was obtained by usage of the primers PPM1 (CGCGGATCCGCTGCGACTATCGAGGTACGC), containing a suitable BamH I cloning site (underlined within the primer sequence), and PPM2 (CCCAAGCTTACCCTTAGGACAAAAGACAACCC), containing a Hind III site (underlined within the primer sequence), and high fidelity $P f u$ DNA polymerase (Invitrogen).

The PCR amplified fragments were eluted from agarose gel, cloned into pGEM-T Easy vector (Promega) and subcloned into the Bam $\mathrm{H}$ I and Hind III sites of the expression vector pQE30 (QiaExpressionist-QiaGen), which contains a $\mathrm{N}$-terminal $\mathrm{His}_{6}$-tag extension, resulting in the pQE30-SnOLP construct. The recombinant clones were selected by using 5 -bromo-4-chloro-3-indolyl- $\beta$-D galatopyranoside (X-Gal)/Isopropyl- $\beta$-D-thiogalactopyranoside (IPTG) blue/white colony screening system and digested with appropriated restriction enzymes. Thereafter, the presence of correct deletion mutations and the correct frame were verified by sequencing entirely both strands of the coding region of $\mathrm{His}_{6}$-tagged mature SnOLP, by using an automated $\mathrm{ABI}$ sequencer with BigDye terminator cycle sequencing kit (Perkim-Elmer). Sequences were analyzed by using the UWGCG software Package (Version 9.1 Genetics Computer Group, Wisconsin, Madison, Wisc.).
The pQE30-SnOLP expression construct containing inserts coding for $\mathrm{His}_{6}$-tagged mature SnOLP was introduced into E. coli M15 strain (QiaGen) competent cells using standard transformation techniques.

\section{Overexpression of $\mathrm{His}_{6}$-tagged mature SnOLP in E. coli} Preliminary experiments with the pQE30-SnOLP expression construct were performed to determine the solubility of the SnOLP, according to the instructions of manufactures (QiaEXpressionist-QiaGen), and to establish the expression levels of the mature protein. Cells of E. coli M15 strain carrying out the construct were cultured overnight at $37^{\circ} \mathrm{C}$ in $5 \mathrm{~mL}$ of Luria-Bertani (LB) medium containing $100 \mu \mathrm{g} / \mathrm{mL}$ ampicillin and $25 \mu \mathrm{g} / \mathrm{mL}$ kanamycin (i.e. LB selective medium) under vigorous agitation (200 rpm). This pre-inoculum suspension was then used to inoculate $500 \mathrm{~mL}$ fresh LB selection medium, which was agitated until an O.D. 600 of 0.6 was reached. Thereafter, an aliquot of non induced control cells was colleted and reserved, and the expression of $\mathrm{His}_{6}$-tagged mature SnOLP protein was induced in the left cells by addition of IPTG to a final concentration of $0.4 \mathrm{mM}$. The cells were cultivated at $37^{\circ} \mathrm{C}$ for $3 \mathrm{~h}$ in the induction medium (i.e. LB selective medium plus IPTG) and afterwards collected by centrifugation at $4.000 \mathrm{~g}$ at $4^{\circ} \mathrm{C}$ for $20 \mathrm{~min}$.

\section{Purification of the His $_{6}$-tagged mature SnOLP protein}

As an attempt to determine the solubility of the protein, an aliquot of soluble fraction was recovered after centrifugation of cellular lysate, obtained from an aliquot of induced pelleted cells by using lysis buffer $(50 \mathrm{mM}$ potassium phosphate buffer pH 7.8, $400 \mathrm{mM} \mathrm{NaCl}, 100 \mathrm{mM}$ $\mathrm{KCl}, 0.5 \%$ Triton $\mathrm{X}-100,10 \%$ glycerol, $10 \mathrm{mM}$ Imidazole), under native conditions.

For a larger scale experiment, the pelleted cells were resuspended in denaturing lysis buffer $(0.1 \mathrm{M}$ Tris. $\mathrm{HCl}, 6 \mathrm{M}$ Urea, pH 8.0) and the cellular suspension was maintained under gentle shaking for 1 hour at room temperature. Cellular debris were removed by centrifugation at $10.000 \mathrm{~g}$ for $25 \mathrm{~min}$ at $4^{\circ} \mathrm{C}$ in order to obtain the solubilized fraction from the supernatant. Final purification of $\mathrm{His}_{6}{ }^{-}$ tagged mature SnOLP was performed by high-performance immobilized-metal ion affinity chromatography (IMAC) on $10 \mathrm{~mL}$ batches of 50\% Nickel-nitrilotriaceticacid (Ni-NTA) resins (QiaEXpressionist-QiaGen), under constant shaking for 1 hour. In order to eliminate proteins nonspecifically bound to the column, the resin was submitted to the washing solution $(0.1 \mathrm{M}$ Tris. $\mathrm{HCl}, 6 \mathrm{M}$ Urea, $20 \mathrm{mM}$ Imidazol, $\mathrm{pH}$ 8.0) and afterwards the recombinant protein was eluted in two steps by using $10 \mathrm{~mL}$ of $0.1 \mathrm{M}$ Tris. $\mathrm{HCl}, 6 \mathrm{M}$ Urea, $200 \mathrm{mM}$ Imidazol, $\mathrm{pH}$ 8.0. The eluted fractions were collected and reserved until use. 


\section{Protein gel and Western blotting analysis}

Protein expression and purification were monitored by sodium dodecyl sulfate-polyacrilamide gel electrophoresis (SDS-PAGE) [55]. Typically, an aliquot of $50 \mu \mathrm{l}$ of soluble and insoluble fractions were mixed with loading buffer (1:1) consisting of $250 \mathrm{mM}$ Tris-HCl pH 6.8, 150 $\mathrm{mM}$ dithiothreitol, 35\% (w/v) glycerol, $7 \%$ SDS and $0.2 \%$ $(\mathrm{w} / \mathrm{v})$ bromophenol blue, and boiled for $5 \mathrm{~min}$. Protein samples were electrophoresed on 12\% SDS-PAGE gels and visualized by Comassie Blue staining (10\% (v/v) methanol, $10 \%(\mathrm{v} / \mathrm{v})$ acetic acid and $0.0125 \%(\mathrm{w} / \mathrm{v})$ Comassie G-250). The distaining solution was $10 \%(\mathrm{v} / \mathrm{v})$ methanol and $10 \%(\mathrm{v} / \mathrm{v})$ acetic acid in water.

For Western blotting, following SDS-PAGE, the protein samples were transferred onto nitrocellulose Hybond membranes (Amersham Pharmacia) using a semi-dry blotting cell (BioRad). The membranes were blocked and incubated with $\mathrm{His}_{6}$ monoclonal antibody (Clontech), according to the instructions of manufacturer $(1: 5000$ dilutions) for $60 \mathrm{~min}$. After washing the membranes, the blot was incubated with anti-mouse IgG secondary antibody conjugated to alkaline phosphatase (Sigma) (1:5000 dilution) for $60 \mathrm{~min}$. Immunoreactive bands were detected colorimetrically by immersing the blot into alkaline phosphatase substrate solution $(0.3 \mathrm{mg} / \mathrm{ml}$ nitro blue tetrazolium (NBT) and $0.15 \mathrm{mg} / \mathrm{ml}$ 5-bromo-4chloro-3-inodolyl phosphate (BCIP) in $0.1 \mathrm{M}$ Tris $\mathrm{pH} 9.5$, $0.1 \mathrm{M} \mathrm{NaCl}, 50 \mathrm{mM} \mathrm{MgCl}_{2}$ ).

\section{Refolding of recombinant SnOLP}

Renaturation of solubilized mature $\mathrm{His}_{6}$-SnOLP was performed by dropwise mixing purified SnOLP protein under denaturing conditions into refolding buffer $(20 \mathrm{mM}$ Tris. $\mathrm{HCl} \mathrm{pH}$ 7.5, $500 \mathrm{mM} \mathrm{NaCl}, 10 \mathrm{mM}$ reduced glutathione, $1 \mathrm{mM}$ oxidized glutathione, and 20\% (w/v) glycerol), at $4^{\circ} \mathrm{C}$, under stirring, in a protein:buffer ratio of 1:10. After repeated dialysis processes, at $4^{\circ} \mathrm{C}$, performed with deionized water to slowly remove denaturants, the recombinant protein was concentrated by lyophilization. Lyophilized recombinant SnOLP was resuspended in water for use in in vitro bioassays. Protein concentration was determined spectrophotometrically by the method of the Bradford [56], using Bio Rad Protein Assay with Bovine Serum Albumin (BSA) as the standard.

\section{Fungal growth inhibition bioassays}

The purified and refolded recombinant SnOLP protein was assayed for its ability to inhibit the in vitro mycelial growth of plant pathogenic oomycete and fungi, essentially as described by Abad et al. [15]. The pathogens used for the tests were Macrophomina phaseolina (Tassi) Goidanich and Fusarium solani (Mart.) f. sp.glycines isolates from Glycine max (soybean), Colletotrichum gloesporioides (Penz.) Penz \& Sacc. isolate from Stylosanthes guianen- sis, Colletotrichum gossypii South. var.cephalosporioides Costa isolate from Gossypium hirsutum (cotton), and Phytophthora nicotiana (Breda de Haan) var.parasitica (Dast.) Waterh isolate from Citrus sp. All fungi were cultivated in PDA (potato dextrose agar, Sigma) and the oomycete $P$. nicotiana var. parasitica was grown in CA (carrot agar) from mycelial disc placed at the center of agar plates, for up to three days. Then, sterile paper discs were positioned adjacent to the growing colony margin and saturated with 10 $\mu \mathrm{L}$ of either BSA $10 \mu \mathrm{g}$ (Sigma) as a negative control, or Nistatin (Micostatin $2000 \mathrm{U}$; generic pharmaceutical) as a positive control, or of recombinant refolded SnOLP protein to different doses $(1,2$ or $3 \mu \mathrm{g})$. The plates were further incubated and daily monitored for up to twelve days. Experiments were conducted with three replicates, digitally photographed and the area of mycelial growth inhibition was measured (Free software: UTHSCSA Image Tool, Version 3.00) [57] for each pathogen and for each concentration of SnOLP separately. Statistical analyses were performed to compare the average areas of mycelial growth inhibition by using ANOVA and Tukey Test at the probability level of 1\% (Software: Genes) [58].

\section{Competing interests}

The author(s) declare that they have no competing interests.

\section{Authors' contributions}

MAC: She carried out the cloning, expression and purification of SnOLP. Moreover, she helped MSS to analyze the bioassays and drafted the manuscript. MSS: She carried out the bioassays and the analyzes related to them. Moreover, she drafted the manuscript. CPM: He carried out the refolding of SnOLP and helped out MSS on the bioassays. SGR: She carried out the cloning, expression and purification of SnOLP together with MAC. RPDS: He carried out the refolding of SnOLP together with CPM and helped out MSS on the bioassays. EAV: He carried out all the statistical analyzes of the bioassays and drafted the manuscript. MFGS: She is the senior researcher and leader of the present group. She has been involved in drafting the manuscript and revising it critically for important intellectual content. Moreover, she has given final approval of the version to be published.

\section{Acknowledgements}

The authors thank Dr. Marcos Antonio Machado (Centro APTA de Citrus, IAC, Cordeirópolis-SP, Brazil) for providing the Phytophthora nicotiana var. parasitica isolate, Dr. Leila Costamilan (Embrapa Trigo, Passo Fundo-RS, Brazil) for providing the Fusarium solani f. sp. glycines isolate, Dr. Nelson Dias Suassuna (Embrapa Algodão, Campina Grande-PB, Brazil) for providing the Colletotrichum gossypii var. cephalosporioides isolate and Dr. Maria José D'Ávila Chachar (Embrapa Cerrados, Planaltina-DF, Brazil) for providing the Colletotrichum gloesporioides and Macrophomina phaseolina isolates. We are also grateful for the technical support received from Cleiton Carlos M. da Cruz (Embrapa Recursos Genéticos e Biotecnologia, Brasília-DF, Bra- 
zil). The authors render special thanks to Dr. Marcel Prins and Dr. Rob Goldbach (Wageningen University and Research Centrum-WUR, Wageningen, The Netherlands), who provided infra-structure at the Laboratory of Virology (WUR) for the expression and purification of the recombinant SnOLP protein. The present work was financially supported by CNPq, FAPDF and Embrapa.

\section{References}

I. Hammond-Kosack K, Jones JDG: Response to plant pathogens. Biochemistry and Molecular Biology of Plants I st edition. 2000: I I 02-I I 56 [http://www.aspb.org/publications/biotext/intros/ch21.cfm]. Rockville, MD, USA: American Society of Plant Physiologists

2. Broekaert WF, Cammue BPA, De Bolle MFC, Thevissen K, De Samblanx GW, Osborn RW: Antimicrobial peptides from plants. Crit Rev Plant Sci 1997, 16:297-323.

3. van Loon LC, van Strien EA: The families of pathogenesisrelated proteins, their activities, and comparative analysis of PR-I proteins. Physiol Mol Plant Pathol 1999, 55:85-97.

4. Christensen $\mathrm{H}$ : The molecular characterization of two barley proteins establishes the novel PR-I 7 family of pathogenesisrelated proteins. Mol Plant Pathol 2002, 3:|35-|44.

5. van Loon LC, Rep M, Pieterse CMJ: Significance of Inducible Defense-related Proteins in Infected Plants. Annu Rev Phytopathol 2006, 44: I35-162.

6. Nelson DE, Raghothama KG, Singh NK, Hasegawa PM, Bressan RA: Analysis of structure and transcriptional activation of an osmotin gene. Plant Mol Biol 1992, 19:577-588.

7. Zhu B, Chen THH, Li PH: Activation of two osmotin-like protein genes by abiotic stimuli and fungal pathogen in transgenic potato plants. Plant Physiol 1995, 108:929-937.

8. Sato F, Kitajima S, Koyama T, Yamada Y: Ethylene-induced gene expression of osmotin-like protein, a neutral isoform of tobacco PR-5, is mediated by the AGCCGCC cis-sequence. Plant Cell Physiol 1996, 37:249-255.

9. Neale AD, Walleithner JÁ, Lund M, Bonnet HT, Kelly A, Meeks-Wagner DR, Peacock WJ, Dennis ES: Chitinase, $\beta$-I,3-glucanase, osmotin, and extensin are expressed in tobacco explants during flower formation. Plant Cell 1990, 2:673-684.

10. Salzman RA, Tikhonova I, Bordlon BP, Hasegawa PM, Bressan RA: Coordinate accumulation of antifungal proteins and hexoses constitutes a developmentally controlled defense response during fruit ripening in grape. Plant Physiol 1998, I I 7:465-472.

II. Singh NK, Braker CA, Hasegawa PM, Handa AK, Hermodson MA, Pfankoch E, Regnier FE, Bressan RA: Characterization of osmotin. Plant Physiol 1987, 85:529-536.

12. LaRosa PC, Singh NK, Hasegawa PM, Bressan RA: Stable NaCl tolerance of tobacco cells is associated with enhanced accumulation of osmotin. Plant Physiol 1989, 91:855-86I.

13. Newton SS, Duman JG: An osmotin-like cryoprotective protein from bittersweet nightshade Solanum dulcamara. Plant Mol Biol 2000, 44:581-589.

14. Roberts WK, Selitrennikoff CP: Zeamatin, an antifungal protein from maize with membrane-permeabilizing activity. J Gen Microbiol 1990, 136:177|-1778.

15. Abad LR, D'Urzo MP, Liu D, Narasimhan ML, Reuveni M, Zhu JK, Niu $X$, Singh NK, Hasegawa PM, Bressan RA: Antifungal activity of tabacco osmotin has specificity and involves plasma membrane permeabilization. Plant Sci 1996, I I 8: I I-23.

16. Anzlovar S, Serra MD, Demastia M, Menestrina G: Membrane permeabilizing of pathogenesis-related protein linusitin from flax seed. Mol Plant-Microbe Inter 1998, 7:610-6I7.

17. Yun DJ, Zhao Y, Pardo JM, Narasimhan ML, Damsz B, Lee M, Abad LR, D'Urzo MP, Hasegawa PM, Bressan RA: Stress proteins on the yeast cell surface determine resistance to osmotin, a plant antifungal protein. Proc Nat Acad Sci 1997, 94:7082-7087.

18. Bray EA, Bailey-Serres J, Weretilnyk E: Responses to abiotic Stress. Biochemistry and Molecular Biology of Plants Ist edition. 2000:II58-1203 [http://www.aspb.org/publications/biotext/intros/ ch22.cfm]. Rockville, MD, USA: American Society of Plant Physiologists

19. Ibeas JI, Lee H, Damsz B, Prasad DT, Pardo JM, Hasegawa PM, Bressan RA, Narasimhan ML: Fungal cell wall phosphomannans facilitate the toxic activity of a plant PR-5 protein. Plant J 2000, 23:375-383.
20. Grenier J, Potvin C, Trudel J, Asselin A: Some thaumatin-like proteins hydrolyse polymeric beta-I,3-glucanase. Plant J I999, 19:473-480.

21. Menu-Bouaouiche L, Vriet C, Peunmans WJ, Barre A, van Damme EJ, Rouge P: A molecular basis for the endo-beta I,3-glucanase activity of the thaumatin-like proteins from edible fruits. Biochemie 2003, 85:|23-|3|.

22. Narasimhan ML, Damsz B, Coca MA, lbeas JI, Yun DJ, Pardo JM, Hasegawa PM, Bressan RA: A plant defense response effector induces microbial apoptosis. Mol Cell 200I, 8:921-930.

23. Ross H: Potato breeding - Problems and perspectives: Advances in Plant Breeding. J Plant Breed I986: I- 130.

24. Colon LT, Eijlander R, Bulding DJ, van ljzedoon MT, Pieterse MMJ, Hoogendoorn J: Resistance to potato late blight(Phytophthora infestans (Mont.) de Bary) in Solanum nigrum, S. villosum and their sexual hybrids with $S$. tuberosum and $S$. demissum. Euphytica 1993, 66:55-64.

25. Edmonds JM, Chweya JA: Promoting the conservation and use of underutilized and neglected crops. I5: Black nightshades. Solanum nigrum L. and related species 1997 [http://www.bioversityinternational.org/Publica tions/Pdf/337.pdf]. Gatersleben, Germany: Institute of Plant Genetics and Crop Plant Research,/Rome, Italy: International Plant Genetic Resources Institute

26. Vleeshouwers VGAA, van Dooijeweert W, Govers F, Kamoun S, Colon LT: Does basal PR gene expression in Solanum species contribute to non-specific resistance to Phytophthora infestans? Physiol Mol Plant Pathol 2000, 57:35-42.

27. Colao MC, Lupino S, Garzillo AM, Buonocore V, Ruzzi M: Heterologous expression of Iccl gene from Trametes trogii in Pichia pastoris and characterization of the recombinant enzyme. Microb Cell Fact 2006, 5:31-42.

28. Ergin A, Büssow K, Sieper J, Thiel A, Duchmann R, Adam T: Homologous high-throughput expression and purification of highly conserved E coli proteins. Microb Cell Fact 2007, 6: 18-30.

29. Sato F, Koiwa H, Sakai Y, Kato N, Yamada Y: Synthesis and secretion of tobacco neutral PR-5 protein by transgenic tobacco and yeast. Biochem Biophys Res Commun 1995, 21 I:909-913.

30. Faus I, Patiño C, del Río JL, del Moral C, Barroso HS, Rubio V: Expression of a synthetic gene encoding the sweet-tasting protein thaumatin in Escherichia coli. Biochem Biophys Res Commun 1996, 229:121-127.

3I. Hu X, Reddy ASN: Cloning and expression of a PR5-like protein from Arabidopsis: inhibition of fungal growth by bacterially expressed protein. Plant Mol Biol 1997, 34:949-959.

32. Campos MA, Ribeiro SG, Rigden DJ, Monte DC, Grossi de Sá MF: Putative pathogenesis-related genes within Solanum nigrum var. americanum genome: isolation of two genes coding for PR5-like proteins, phylogenetic and sequence analysis. Physiol Mol Plant Pathol 2002, 6 I:205-216.

33. Bol JF, Linthorst HJM, Cornelissen BJC: Plant pathogenesisrelated proteins induced by virus infection. Ann Rev Phytopathol 1990, 28: I 13-138.

34. Melchers LS, Sel-Buurlage MB, Vloemans SA, Woloshuk CP, van Roekel JSC, Pen J, van der Elzen PJM, Cornelisen BJC: Extracellular targeting of the vacuolar tobacco proteins AP24, chitinase and $\beta-1,3-g l u c a n a s e$ in transgenic plants. Plant Mol Biol 1993, 2l:583-593.

35. Liu D, Rhodes D, D'Urzo MP, Xu Y, Narasimhan ML, Hasegawa PM, Bressan RA, Abad L: In vivo and in vitro activity of truncated osmotin that is secreted into the extracellular matrix. Plant Sci 1996, I2 I:|23-131.

36. Pain RH: Frontiers in Molecular Biology: Mechanisms of Protein Folding New York, USA: Oxford University Press; 1994.

37. Bulaj G: Formation of disulfide bonds in proteins and peptides. Biotecnol Adv 2005, 23:87-92.

38. Huang YH, Hartman GL: Reaction of selected soybean genotypes to isolates of Fusarium solani f. sp. glycines and their culture filtrates. Plant Dis 1998, 82:999-1002.

39. Wrather JA, Anderson TR, Arsyad DM, Tan Y, Popler LD, PortaPuglia A, Ram HH, Yorinori JT: Soybean disease loss estimates for the top ten soybean-producing contries in 1998. Can J Plant Pathol 2001, 23: II5-I2I.

40. Auki T, O'Donnell K, Scandiani MM: Sudden death syndrome of soybean in South America is caused by four species of Fusarium : Fusarium brasiliense sp. nov., F. cuneirostrum sp. nov., $F$. tucumaniae, and F. virguliforme. Mycoscience 2005, 46: I62-I83. 
4I. Almeida AMR, Abdelnoor RV, Arias CAA, Carvalho VP, Jacoud Filho DS, Marin SRR, Benato LC, Pinto MC, Carvalho CGP: Genotypic diversity among Brazilian isolates of Macrophomina phaseolina revealed by RAPD. Fitopatol Bras 2003, 28:279-285.

42. Mengistu A, Paris RL: Comparison of disease assessments of soybean genotypes in the presence of charcoal rot [abstract]. Phytopathol 2003, 93:56I.

43. Mathieson JT, Mangano V: Ramulose, a new cotton disease in Paraguay caused by Colletotrichum gossypii var. cephalosporioides. Summa Phytopathol 1985, I I: I I5-I I8.

44. Davis RM: Phytophthora-induced diseases. In Compendium of Citrus diseases I st edition. Edited by: Whiteside JO, Garnsey SM, Timmer LW. St. Paul. Minnesota, USA: APS Press; 1988:22-24.

45. Erwin DC, Ribeiro OK: Phytophthora diseases worldwide. 1996 [http://shopapspress.stores.yahoo.net/42120.html]. St. Paul, Minnesota, USA: APS Press

46. Muniz MFS, Queiroz FM, Menezes M: Characterization of Phytophthora isolates pathogenic to Citrus sinensis in the State of Alagoas, Brazil. Fitopatol Bras 2004, 29:201-204.

47. Manners JM, He C: Recent advances in studies of anthracnose of Stylosanthes. IV. Molecular approaches to studies of Colletotrichum gloeosporioides, causing anthracnose of Stylosanthes in Australia. Trop Grassl 1997, 3 I:435-444.

48. Chakraborty S, Fernandes CD, Charchar MJd'Á, Thomas MR: Pathogenic variation in Colletotrichum gloesporioides infecting Stylosanthes spp. in a center of diversity in Brazil. Amer Phytopathol Soc 2002, 92:553-562.

49. Jami SK, Anuradha TS, Guruprasad L, Kirti PB: Molecular, biochemical and structural characterization of osmotin-like protein from black nightshade (Solanum nigrum). J Plant Physiol 2007, I 64:238-252.

50. Grenier J, Potvin C, Trudel j, Asselin A: Some thaumatin-like proteins hydrolyze polymeric $\beta$-I,3-glucans. Plant J 1999 19:473-480.

51. Laurence MB, Vriet C, Peumans WJ, Barre A, van Damme EJM, Rouge $P$ : A molecular basis of the endo- $\beta-1,3$-glucanase activity of the thaumatin-like proteins from edible fruits. Biochemie 2003, 85: $|23-| 3 \mid$

52. Kamoun S, Huitema E, Vleeshouwers VGAA: Resistance to oomycetes: a general role for the hypersensitive response? Trends Plant Sci 1999, 4:196-200.

53. Vleeshouwers VGAA, van Dooijeweert W, Govers F, Kamoun S, Colon LT: The hypersensitive response is associated with host and nonhost resistance to Phytophthora infestans? Planta 2000, 210:853-864.

54. Takemoto D, Katsumi F, Doke N, Kawakita K: Identification of chitinase and osmotin-like protein as actin-binding proteins in suspension-cultures potato cells. Plant Cell Physiol 1997, 38:44I-448.

55. Laemlli UK: Clevage of Structural Proteins during the assembly of head of bacteriophage T4. Nature 1970, 227:680-685.

56. Bradford MM: $A$ rapid and sensitive method for the quantitation of microgram quantities of protein utilizing the principle of protein-dye binding. Anal Biochem 1976, 7:248-254.

57. University of Texas Health Science Center in San Antonio (UTHSCSA) Image Tool, Version $\mathbf{3 . 0 0}$ [http://ddsdx.uth scsa.edu/dig/itdesc.html]

58. Cruz CD: Programa Genes (versão Windows): aplicativo computacional em genética e estatística. Viçosa: Editora UFV; 2001 .
Publish with Biomed Central and every scientist can read your work free of charge

"BioMed Central will be the most significant development for disseminating the results of biomedical research in our lifetime. "

Sir Paul Nurse, Cancer Research UK

Your research papers will be:

- available free of charge to the entire biomedical community

- peer reviewed and published immediately upon acceptance

- cited in PubMed and archived on PubMed Central

- yours - you keep the copyright

Submit your manuscript here:

http://www.biomedcentral.com/info/publishing_adv.asp
BioMedcentral 